\title{
Adherence to best care practices in normal birth: construction and validation of an instrument*
}

\author{
Adesão às boas práticas na atenção ao parto normal: \\ construção e validação de instrumento \\ Adhesión a las buenas prácticas en la atención al parto normal: \\ construcción y validación de instrumento
}

Elisabete Mesquita Peres de Carvalho', Leila Bernarda Donato Göttems, Maria Raquel Gomes Maia Pires²

* Extracted from the dissertation "Elaboração de instrumento para análise da adesão dos profissionais às práticas obstétricas seguras na atenção ao parto", Programa de Pós-Graduação Stricto Sensu, Escola Superior de Ciências da Saúde, 2015.

${ }^{1}$ Secretaria de Estado da Saúde do Distrito Federal, Escola Superior de Ciências da Saúde, Programa de Pós- Graduação Stricto Senso em Ciências para a Saúde, Brasília, DF, Brazil.

${ }^{2}$ Universidade de Brasília, Faculdade de Ciências da Saúde, Departamento de Enfermagem, Brasília, DF, Brazil.

\section{ABSTRACT}

Objective: To describe the stages of construction and validation of an instrument in order to analyze the adherence to best care practices during labour and birth. Method: Methodological research, carried out in three steps: construction of dimensions and items, face and content validity and semantic analysis of the items. Results: The face and content validity was carried out by 10 judges working in healthcare, teaching and research. Items with Content Validity Index (CVI) $\geq 0.9$ were kept in full or undergone revisions as suggested by the judges. Semantic analysis, performed twice, indicated that there was no difficulty in understanding the items. Conclusion: The instrument with three dimensions (organization of healthcare network to pregnancy and childbirth, evidence-based practices and work processes) followed the steps recommended in the literature, concluded with 50 items and total CVI of 0.98 .

\section{DESCRIPTORS}

Natural Childbirth; Questionnaires; Validation Studies; Women's Health. 


\section{INTRODUCTION}

The guide for care in normal birth published by the World Health Organization (WHO) in $1996^{(1)}$, product of international discussions based on scientific evidence, was a milestone in promoting healthy births and in response to the high rates of maternal and neonatal morbidity and mortality. Since then, governments and organized civil society have embarked on a crusade in the dissemination and implementation of these practices, which have contributed significantly to the reduction of preventable deaths ${ }^{(2-4)}$.

Healthcare practices to normal birth were classified into four categories, according to usefulness, effectiveness and risk, to guide the professional conduct: A) Practices which are demonstrably useful and should be encouraged; B) Practices which are clearly harmful or ineffective and should be eliminated; C) Practices for which insufficient evidence exists to support a clear recommendation and which should be used with caution while further research clarifies the issue; and D) Practices which are frequently used inappropriately ${ }^{(1,4)}$.

Although there is wide dissemination of this document, the medicalisation is considered one of the greatest problems of maternal health in Brazil. Institutional births, which are performed by trained professionals reach $98 \%$; and in $90 \%$ of cases they are performed by a physician. Drugs, such as oxytocin, have been used in most normal births, while the cesarean section has become the most common means of birth ${ }^{(5-6)}$.

Unnecessary interventions without criteria and high maternal mortality rates in the national and international scenario are still persistent practices. The WHO estimated that in 2013, approximately 289,000 women worldwide died during and following pregnancy and childbirth, with an overall mortality rate of 210 maternal deaths per 100,000 live births ${ }^{(7)}$.

Indeed, many people have been working to change the current model of birth care, defined as technocratic with primacy of hard technology on human relations, women's passivity idea during interventions that shorten the time of birth, practices without scientific evidence and the form of induce birth by professionals ${ }^{(3,8)}$. The incorporation of best birth care practices and reduction of unnecessary interventions are in WHO recommendations, reinforced by the Brazilian Ministry of Health through public policy named Rede Cegonha ${ }^{(9)}$.

The academic literature on the subject is extensive, available and consistent. However, more careful readings indicate that there are still gaps in the understanding of the potential and limitations in the work process of professionals employed in healthcare service, with low adherence to best obstetric practices. Adherence is a dynamic, multifunctional and behavioral process that results from a set of determinants that depend on subjective factors. It is a decision process mediated by personality traits, intellectual cognitive level, beliefs and social context of which the individual is $\operatorname{part}^{(10)}$. Having appropriate professional attitudes with encouragement and technical knowledge is adhering to best practices.
Analysis of adherence can be made by methods of direct and/or indirect observation through objective and validated psychometric instruments ${ }^{(10)}$. Adherence to best practice here was treated as construct being measured (latent variable) through indirect observation of its manifestations in the daily health work process in the context of the healthcare network to pregnancy and childbirth ${ }^{(11)}$. These manifestations are the items (operational concepts) of adherence, which constitute attitudes, behaviors, anxieties, opinions on health, physical and psychological well-being of women informed through a process of selfdescription or observer assessment. Items were defined in three dimensions of adherence - organization of the network of healthcare during pregnancy, labour and childbirth; obstetric practices based on scientific evidence; and work processes.

Thus, the research question was: What variables related to the organization of the healthcare network to pregnancy, labour and childbirth, and the work process may indicate adherence to best care practices in birth? The objective of this study is to describe the stages of construction and validation of an instrument in order to analyze the adherence to best care practices during pregancy and birth.

\section{METHOD}

We conducted a methodological research for construction, content and face validity of the items for a questionnaire on adherence to best care practices to birth. The methodological research investigates, organizes and analyzes data to build, validate and evaluate tools and techniques focused on the development of specific data collection instruments ${ }^{(12)}$.

In the process of constructing an instrument for measurement, one should note aspects of validity and reliability. The validity is present when it measures, in fact, what is proposed to be measured in relation to a particular phenomenon investigated. Reliability is the instrument's ability to present accurate measures to reality ${ }^{(13)}$. Validity is a research process that starts with the construction and persists during the development stages, enforcement, correction and interpretation of results. The interpretation of the validity of a test sometimes also requires the calculation of different coefficients ${ }^{(13-15)}$. The present study design followed three steps:

\section{Step 1 - Construction of Instrument Items}

From extensive literature review, including publications, international, national and local protocols, an Analysis $\mathrm{Ma}^{-}$ trix (Chart 1) was built, structured in three dimensions, which led to the variables (items).

\section{Step 2 - Content AND face VAlidity Items}

Content validity consists in analyses of to what extent the items designed to measure a theoretical construct effectively represent all the important aspects of the concept to be measured ${ }^{(18)}$. Face validity with regard to language, understanding and appropriateness of items ${ }^{(19)}$. 
Chart 1 - Matrix analysis for adherence of health professionals to evidence-based practice of healthcare during labour and birth Brasilia, DF, Brazil, 2014.

\begin{tabular}{|c|c|c|}
\hline Dimension & Definition & Indicators \\
\hline $\begin{array}{l}\text { Organization } \\
\text { of Healthcare } \\
\text { Network for } \\
\text { Pregnancy, } \\
\text { labour and } \\
\text { childbirth }\end{array}$ & $\begin{array}{l}\text { - Bonding map: Instrument organizing the movement of pregnant } \\
\text { women flow between prenatal and birth }{ }^{(9)} \text {. } \\
\text { - Infrastructure and ambience: Environment with capacity for } \\
\text { one or two beds and attached bathroom for the assistance } \\
\text { to women in all clinical stages of labour, which favors the } \\
\text { presence of a companion and provides conditions for use of } \\
\text { non-pharmacological methods of pain relief and stimulating the } \\
\text { physiological evolution of labour }{ }^{(16)} \text {. }\end{array}$ & $\begin{array}{l}\text { - Professionals know the region/territory of reference. } \\
\text { - Bonding practices between prenatal care and } \\
\text { maternity are held. } \\
\text { - Existence of soft technologies for non- } \\
\text { pharmacological pain relief. } \\
\text { - Demands that encourage the use of soft } \\
\text { technologies for non-pharmacological pain relief. }\end{array}$ \\
\hline $\begin{array}{l}\text { Obstetric } \\
\text { Practice } \\
\text { Based on } \\
\text { Scientific } \\
\text { Evidence }\end{array}$ & $\begin{array}{l}\text { Knowledge and use of practices based on scientific evidence: } \\
\text { process that promotes the solution of healthcare problems for } \\
\text { clinical decision making based on the best evidence }{ }^{(17)} \text {. }\end{array}$ & $\begin{array}{l}\text { - Acceptance or rejection of demonstrably useful } \\
\text { practices. } \\
\text { - Disagreement or not to practices that are clearly } \\
\text { harmful and used improperly. } \\
\text { - Usage (or not) of useful practices. }\end{array}$ \\
\hline $\begin{array}{l}\text { Work } \\
\text { Processes in } \\
\text { Health }\end{array}$ & $\begin{array}{l}\text { - Existence of protocols that guide the work process during labour } \\
\text { and birth: Protocols that guide Labour and Birth within the } \\
\text { principle of humanization and recommended practices by } \mathrm{WHO}^{(1)} \text {. } \\
\text { - Scientific knowledge as a productive force: Health professionals } \\
\text { working in partnership, sharing information, decision making and } \\
\text { continuous training. }\end{array}$ & $\begin{array}{l}\text { - Medical models centered on procedures. } \\
\text { - Predominantly intangible capital (knowledge as the } \\
\text { primary productive force). }\end{array}$ \\
\hline
\end{tabular}

For content validity, a reasoned guide on the principles of development for Pasquali psychological scales was built ${ }^{(20)}$. In this analysis, experts judge whether the items were appropriate to the attributes of theoretical construct.

We used the Content Validity Index (CVI) to identify the degree of agreement among experts during the review process of the answers ${ }^{(18,21)}$. This index allowed us to analyze each item individually and then the instrument as a whole. An agreement of over $90 \%$ among judges was one of the decision criteria on the relevance of the item to which theoretically referred. This cutoff, higher to those recommended in the literature (CVI 0.8) $)^{(20-21)}$, was used to contemplate the limiting index that measures the agreement of randomness. It was used as additional criteria for the final review of the instrument: a - item redundancy with others existing in the instrument; $\mathrm{b}$ - balance between the items with positive and negative statements in each dimension; $\mathrm{c}$ - frequency suggestions and recommendations made by the judges for each item; $d$ - coherence between the item and the actual conditions of work commonly reported in studies on adherence of professionals to best obstetric practices for childbirth ${ }^{(4)}$.

Judges evaluated each item according to behavioral criteria, objectivity, simplicity, clarity, relevance, variety in relation to language and preferred scales. The criteria were given the following numerical values: (1) Not Representative; (2) Item needs major revision to be representative; (3) Item requires minor review to be representative; (4) Representative ${ }^{(19-20)}$. The index score was calculated by the sum of agreement of the items that were marked by " 3 " or " 4 " by experts (considered as relevant) divided by the total number of responses ${ }^{(18,21)}$.

In each dimension assessed, a space was left so that judges could indicate necessary revisions in items; necessary items, but absent in dimension; unnecessary items in the instrument and comments or suggestions regarding the assessment of the items on the scale ${ }^{(18-21)}$. Concurrently, face validity of the presentation of content, clarity and facility of reading of each item was held.
The invitation to judges was formally held by a cover letter containing: the analysis matrix, the objective of the study, the description of the instrument, information about the context, the target population and why the professional was chosen as a judge ${ }^{(20)}$. Appendices to judges analyses were sent by email and/or printed copies.

A total of 17 top-level professionals, physicians and nurses with proven clinical experience, publications on the subject and methodological knowledge of the construction of questionnaires and scales were invited. We gave a period of 30 days for consideration of the content, which was extended for another 20 days. A total of 10 instruments reviewed returned, sufficient number according to literature recommendations indicating a minimum of five and a maximum of 10 , or at least six experts ${ }^{(18-20)}$. The judges who responded had a mean age of 50 years, three were male and seven were female. With regard to academic education, five were physicians and five were nurses, with a mean of 20.9 years of professional practice.

The Likert scale adopted was well organized: (1) Strongly Disagree; (2) Partly Disagree; (3) Do not Know/ Not Applicable; (4) Partially agree; (5) Totally Agree. We observed the theoretical rating scales with five grades, the middle was neutro ${ }^{(11)}$. After applying a representative sample as a rule of thumb, the aim was to build scores through the sum of the items valuations and create additional interval variables ${ }^{(11)}$.

Each of the 50 items of the three dimensions provided possibility for the answer through the Likert scale of five points (totally disagree - score 1 ; up to totally agree score 5). For example, to the item "I promote the skin to skin contact between mother and newborn, during the first half hour of birth" the higher the score, the higher the adherence but for items that have reverse score (that is, "routine episiotomy is held in this service") the higher score the worst is adherence. The instrument has 22 items with reverse scores $(1,5,6,7,8,11,14,17,18,27,28,29,30,31$, $32,33,39,41,44,48,49,50)$. 


\section{Step 3 - Semantic Analysis}

Semantic analysis aims to verify whether all items are understandable to the population to which the instrument is intended ${ }^{(20)}$. This analysis consists in checking the items in a brainstorming situation. Each item was presented to the group of professionals, asking them to be replicated, in other words, by group members. When the replicated item did not generate any doubt, it was considered completely understood $^{(20)}$.

The instrument was administered to eight health professionals who work in childbirth care, five nurses and three physicians during the month of December 2014. After the adequacy of suggestions, a second analysis was performed during the same month. The project was approved by the Research Ethics Committee of the State Department of Health from Distrito Federal - CEP - SES/DF, under number CAAE 01918712.6.0000.5553, according to Resolution 466/2012 of the Brazilian National Health Council.

\section{RESULTS}

From the analysis of experts, we received back 10 evaluated instruments. Suggestions of changes were made on items in relation to the dimension of the item represented. There was agreement of the judges regarding all the items belonging to the dimension of practices based on scientific evidence. However, with respect to the Organization of Healthcare Network for Pregnancy, Labour and Childbirth and Work Processes disagreement arose missinformation to the relocation of items.

Some changes were made to the items to meet the suggestions of the judges: writing in the first person, to meet the behavioral criteria, restructuring regarding the dimensions and increase to fill identified gaps. The instrument was concluded with 50 items (Chart 2). All changes were made before the Semantic Analysis. The instrument total CVI was $0.98 \%$, which means that the instrument enables measuring the content of what is proposed to measure.

Chart 2 - Agreement of the judges on the criteria of items from the application of CVI tests - Brasilia, DF, Brazil, 2014.

\begin{tabular}{|c|c|}
\hline Items & CVI \\
\hline \multicolumn{2}{|l|}{ Dimension 1 - Organization of Healthcare Network for Pregnancy, Labour and ChildBirth } \\
\hline 1. I am unaware of the coverage area of the labour and birth service. & 0.98 \\
\hline 2. I provide bed in another childbirth care unit when there are available beds in service. & 0.96 \\
\hline 3. This service receives pregnant women to know the place of birth, routinely. & 1 \\
\hline 4. Educational activities are carried out with pregnant women and their companions in this service. & 1 \\
\hline 5. The normal birth is performed in ALIP beds (antepartum, labour and immediate postpartum period) in this service. & 1 \\
\hline 6. The physical space, in this service, makes it difficult to ambulation of the preganant women during labour. & 0.98 \\
\hline 7. They used ALIP beds, the ball, the horse and the birthing stool improperly in this service. & 0.96 \\
\hline 8. The managers of this unit properly size the quantitative of professionals to childbirth demand. & 0.98 \\
\hline 9. In this service, nurses carry out normal births, routinely. & 1 \\
\hline 10. The head of Nursing in this service list exclusive nurses to assist during labour and Childbirth. & 0.95 \\
\hline 11. In this service, we registry information about pregnancy care and birth in different instruments. & 0.91 \\
\hline 12. Professionals use the information about prenatal recorded in the electronic medical records of pregnant women. & 1 \\
\hline 13. In this service, I receive pregnant women with individual birth plan prepared during the prenatal. & 0.96 \\
\hline \multicolumn{2}{|l|}{ Dimension 2 - Obstetric Practice Based on Scientific Evidence } \\
\hline 14. I restrict the water and food intake of the preganant women during labour, routinely. & 1 \\
\hline 15. I use alternative means to preserve the privacy of the preganant women in the collective antepartum. & 1 \\
\hline 16. I encourage their right for a companion of free choice of the mother. & 1 \\
\hline 17. I recognize in the companion a barrier for the care of the preganant women. & 1 \\
\hline 18. The companion is rarely informed of the woman's condition. & 1 \\
\hline 19. I give orientations on ways of relaxation for pain relief during Labour and Childbirth. & 1 \\
\hline 20. We used routinely non-pharmacological methods of pain relief such as massage and relaxation techniques. & 1 \\
\hline 21. I encourage freedom of labouring woman's position during Labour and Childbirth. & 1 \\
\hline 22. In this service, we performe auscultation of fetal heart rate every 30 min., routinely. & 1 \\
\hline 23. The partograph is routinely used to monitor childbirth. & 1 \\
\hline 24. I offer information to the woman in labour on the evolution of labour. & 1 \\
\hline 25. I promote premature skin contact between mother and child, routinely. & 1 \\
\hline 26. We avoid the performance of routine enema in this service. & 1 \\
\hline 27. We avoid routine shaving in this service. & 1 \\
\hline
\end{tabular}


...continuation

\begin{tabular}{|c|c|}
\hline Items & CVI \\
\hline 28. We use intravenous infusion routinely during Labour and Childbirth, in this service. & 1 \\
\hline 29. Intravenous oxytocin is routinely used as a way to speed up labour in this service. & 1 \\
\hline 30. We encourage the pregnant women to make an effort at the time of fetus expulsion. & 1 \\
\hline 31. Episiotomy is carried out routinely in this service. & 1 \\
\hline 32. Vaginal touches are performed by professionals to assess dilation. & 0.9 \\
\hline 33. We perform the Kristeller maneuver when necessary. & 1 \\
\hline 34. Early amniotomy is routinely performed in this service. & 1 \\
\hline 35. The labouring woman is transferred to the childbirth room. & 1 \\
\hline \multicolumn{2}{|l|}{ Dimension 3 - Working Process } \\
\hline 36. I use the care protocols during labour and birth. & 1 \\
\hline 37. The protocols that guide birth care are difficult to access for professionals. & 1 \\
\hline 38. In this service, I account for how I act. & 0.86 \\
\hline 39. Medical interventions are unquestionable in this service. & 0.83 \\
\hline 40. Pregnant women are consulted before the interventions that accelerate labour process are implemented. & 1 \\
\hline 41. In this service, clinical decisions are shared with the staff on duty. & 0.98 \\
\hline 42. Each professional attending the birth according to their own way. & 0.9 \\
\hline 43. I discuss the scientific evidence with my team. & 1 \\
\hline 44. I feel out of date with respect to scientific evidence. & 1 \\
\hline 45. Physicians and nurses work integrated in this service. & 1 \\
\hline 46. Normal births are stimulated by the multidisciplinary team here. & 1 \\
\hline 47. I usually care for usual and risky labour in a similar way. & 1 \\
\hline 48. The childbirth care by non medical professionals is restricted. & 1 \\
\hline 49. In this service, professionals are trained. & 1 \\
\hline 50. Satisfaction surveys of users are carried out here. & 1 \\
\hline
\end{tabular}

In dimension 1 , corresponding to the items 1 to 12 , the following changes were made: items 5 and 6 were reassigned to dimension 2 and the item and 9 for Dimension 3. Items number $7(\mathrm{CVI}=0.96)$, number $8(\mathrm{CVI}=0.98)$, number 10 $(\mathrm{CVI}=0.95)$ and number $11(\mathrm{CVI}=0.91)$, although with a high CVI, received ammendement suggestions for greater objectivity, clarity and avoid redundancies. Item 7 was excluded because it did not meet the criteria of simplicity, as expressed various ideas could make the respondent confused. The contents of this item are showed on items 13 and 21 of the final version of the instrument. Item 8 has changed and has become item 6 of the final version. Items 10 and 11 were revised and are now part of dimension 3 (47 and 50 respectively). Items 8, 9, 10 and 11 were added to the final version of the instrument through the suggestions of the judges.

In dimension 2, corresponding to items 13-35, the following changes were made: the items 5 and 6 were relocated to dimension 1. Only item $35(\mathrm{CVI}=1.0)$ has been deleted, after evaluation of the researchers and judges suggestions did not meet the relevance and reliability criteria.

In dimension 3, corresponding to items 36-50, the following changes were made: the items 37,38 and 39 were excluded. Item $37(\mathrm{CVI}=1.0)$ was excluded for being contemplated in item 36 . The items 38 and 39 were excluded because they received CVI 0.86 and 0.83 , respectively, and for recommendations of the judges. The way they were written was considered inapropriate and did not express desirable or preferred attitudes, and could lead to bias in the answers.

Chart 3 - Structure and organization of the Instrument for analysis of adherence of health professionals to safe and secure obstetric practices in birth care - Brasilia, DF, Brazil, 2014.

\begin{tabular}{|c|c|c|c|c|c|c|}
\hline & Items & 1 & 2 & 3 & 4 & 5 \\
\hline 01 & $\begin{array}{l}\text { I am unaware of the coverage area of the labour and birth service. } \\
\text { nascimento. }\end{array}$ & & & & & \\
\hline 02 & I provide bed in another childbirth care unit when there are available beds in service. & & & & & \\
\hline 03 & We receive pregnant women get to know the place of birth, routinely. & & & & & \\
\hline 04 & $\begin{array}{l}\text { Educational activities are carried out with pregnant women and companions to encourage the motherhood } \\
\text { bonding, in the previous visit. }\end{array}$ & & & & & \\
\hline
\end{tabular}




\begin{tabular}{|c|c|c|c|c|c|c|}
\hline & Items & 1 & 2 & 3 & 4 & 5 \\
\hline 05 & We usually serve a higher number of pregnant women when compared to the number of beds we have. & & & & & \\
\hline 06 & The team is insufficient for the amount of pregnant women attended daily. & & & & & \\
\hline 07 & We care for pregnant women without the individual birth plan prepared during the prenatal. & & & & & \\
\hline 08 & Overall, we receive women in labour without all results of risk screening tests performed in prenatal care. & & & & & \\
\hline 09 & It is easy to hire prenatal team professionals of primary care and/or high-risk clinic when necessary. & & & & & \\
\hline 10 & I participate in meetings with prenatal teams to discuss improvements in care during pregnancy, labour and birth. & & & & & \\
\hline 11 & $\begin{array}{l}\text { When we need support from available diagnostic and therapeutic procedures, we have difficulty getting these } \\
\text { services. }\end{array}$ & & & & & \\
\hline 12 & Access to information held by other health units is facilitated by the electronic medical record. & & & & & \\
\hline 13 & The normal birth is performed in ALIP beds (antepartum, labour and immediate postpartum period) in this service. & & & & & \\
\hline 14 & We restrict the water and food intake of the pregnant women during labour, routinely. & & & & & \\
\hline 15 & We use blinds and/or screens to preserve the privacy of the mother in the collective antepartum. & & & & & \\
\hline 16 & I encourage the presence of a companion of free choice of the pregnant women. & & & & & \\
\hline 17 & I recognize that the companion complicates the care of the mother. & & & & & \\
\hline 18 & The companion is rarely informed of the woman's condition. & & & & & \\
\hline 19 & I recommend ways of relaxation for pain relief during Labour and Childbirth. & & & & & \\
\hline 20 & I encourage pregnant women to walk during labour. & & & & & \\
\hline 21 & I use non-pharmacological methods of pain relief such as massage and relaxation techniques. & & & & & \\
\hline 22 & I encourage freedom of Labouring woman's position during Childbirth. & & & & & \\
\hline 23 & In the active phase of labour, we perform auscultation of fetal heart rate every $30 \mathrm{~min}$. , routinely. & & & & & \\
\hline 24 & I use the partograph to monitor labour. & & & & & \\
\hline 25 & I offer information to the women on the evolution of their labour. & & & & & \\
\hline 26 & I promote skin contact between mother and child, in the first half hour after birth. & & & & & \\
\hline 27 & The performance of enema is routinely in preparation for labour. & & & & & \\
\hline 28 & The shaving is routinely performed in this service. & & & & & \\
\hline 29 & We use intravenous hydration during the Labour and Birth. & & & & & \\
\hline 30 & Intravenous oxytocin is used in conducting the labour. & & & & & \\
\hline 31 & We encourage the pregnant women to make an effort at the time of fetus expulsion. & & & & & \\
\hline 32 & Episiotomy is carried out routinely in this service. & & & & & \\
\hline 33 & We avoid performing vaginal touches for more than a professional. & & & & & \\
\hline 34 & We perform the Kristeller maneuver when necessary. & & & & & \\
\hline 35 & Early amniotomy is rarely performed in this service. & & & & & \\
\hline 36 & We follow the Brazilian Ministry of Health recommendations for labour and birth. & & & & & \\
\hline 37 & Pregnant women are consulted before the interventions that accelerate labour process are implemented. & & & & & \\
\hline 38 & In this service, clinical decisions are shared with the staff on duty. & & & & & \\
\hline 39 & Each professional assists childbirth according to their experience. & & & & & \\
\hline 40 & We discuss the scientific evidence about care during labour and birth with my team. & & & & & \\
\hline 41 & I feel out of date with respect to scientific evidence. & & & & & \\
\hline 42 & Physicians and nurses work integrated in this service. & & & & & \\
\hline 43 & Normal births are stimulated by the multidisciplinary team here. & & & & & \\
\hline 44 & I usually care for usual and risky labour in a similar way. & & & & & \\
\hline 45 & In this service, the professionals are trained periodically. & & & & & \\
\hline 46 & Satisfaction surveys of users are carried out here. & & & & & \\
\hline 47 & I record information about the care during labour and birth only in electronic medical records. & & & & & \\
\hline 48 & I rarely consult the information about prenatal recorded in the prenatal registry. & & & & & \\
\hline 49 & Trainings offered for professionals of this team are rare. & & & & & \\
\hline 50 & Nurses' birth care is restricted to a few shifts (scarce). & & & & & \\
\hline
\end{tabular}




\section{DISCUSSION}

The construction of the instrument items was carried out after extensive literature review of studies on obstetric practices based on evidence, working processes and healthcare networks (HCN). In addition, we sought to develop items that corresponded to individual behaviors and attitudes and groups that influence the implementation of actions and services ${ }^{(22-24)}$.

There was ease in the creation of items in relation to best childbirth care practices (eating and movement during labour and childbirth, use of non-pharmacological methods for pain relief and monitoring of labour by partograph) and obstetric interventions (intravenous hydration, oxytocin to speed up labour, amniotomy, Kristeller maneuver and episiotomy). This is due to the significant number of publications on the subject, as well as international, national and local protocols ${ }^{(1,9,23)}$.

In items related to the working process and new practices arising from the $\mathrm{HCN}$, the challenge was to develop those related to: institutional values, existence of dialogical spaces, making shared decisions, enhancement of scientific knowledge of health professionals, use of bonding maps, territorial health facility and prior visit to maternity. This difficulty was also observed in the evaluation carried out by the judges as there were disagreements that led to the relocation of the items in the dimensions ${ }^{(9,25)}$. Regarding the items of the Network Organization to Pregnancy, Labour and Childbirth, it is noteworthy that the items 1, 2, 3 and 10 refer to attitudes of professionals. The other measure the contribution of infrastructure and logistics services for favoring the joint work and sharing objectives and recommended information on $\mathrm{HCN}^{(9)}$.

The expertise of the judges was crucial to recognize the relevance of the items in relation to construct, assessing comprehension and clarity to the target population of the instrument ${ }^{(20)}$. Studies report that the higher the academic production and the time of experience in the area, the greater professional qualification the person has to play the role of judge in content validity ${ }^{(26)}$.

Items with CVI greater than or equal to 0.9 were kept in full or properly drawn up in accordance with the sug- gestions of the judges. Exception to this rule occurred with item 35 (CVI=1.0), which was excluded for not meeting the relevance and reliability criteria. Services that do not have ALIP beds, transfering the pregnant woman to the childbirth room at birth is required. The absence of this technology is not an impediment to adherence to best obstetric practices. The item thus can induce a negative attitude to the instrument and increase responses errors ${ }^{(20)}$.

These items are considered validated since their content contemplate the scores recommended by the reference adopted in this research ${ }^{(20-21)}$. These results are consistent with other studies ${ }^{(27-28)}$ which consider necessary concordance between the judges of at least $80 \%$ for the CVI.

The instrument was assessed twice for addressing questions of Semantic Analysis. The final version of the instrument consisted of 50 items, divided into Likert scale, with numerical score of 1-5, as shown in Chart 3. The items followed the criteria range suggested by Pasquali, with half in favor and half unfavorable to avoid stereotypical response error to the left or right-hand scale ${ }^{(20)}$.

\section{CONCLUSION}

The construction of the present instrument followed the steps recommended in the literature - literature review, defining dimensions, building items through content and face validity and semantic analysis. There were no significant changes in the content of the items relating to practices based on scientific evidence indicating greater appropriation of the concepts they represent. However, there was relative difficulty in the composition of the items of the dimensions regarding the organization of care network to pregnancy, labour and childbirth, and working processes. It was observed that the new provisions proposed by $\mathrm{HCN}$ and the changes in their work process resulted in greater demand for appropriation by the academic community and health professionals. The instrument consists of 50 items which obtained a total CVI of 0.98 . This study have limitations regarding internal consistency of the instrument for which it is recommended to be applied to a greater sample of professionals working in neonatal care, to construct validity, reliability and internal consistency.

\section{RESUMO}

Objetivo: Descrever as etapas de construção e validação de um instrumento para análise da adesão às boas práticas na atenção ao parto e nascimento. Método: Pesquisa metodológica, realizada em três etapas: elaboração de dimensões e itens, validação aparente e de conteúdo e análise semântica dos itens. Resultados: A validade aparente e de conteúdo foi realizada por 10 juízes que atuam na assistência, ensino e pesquisa. Os itens com Índice de Validade de Conteúdo (IVC) $\geq$ a 0,9 foram mantidos na íntegra ou sofreram revisões conforme sugestões dos juízes. A análise semântica, realizada duas vezes, indicou que não havia dificuldade na compreensão dos itens. Conclusão: $\mathrm{O}$ instrumento com três dimensões (organização da rede de atenção ao parto e nascimento, práticas baseadas em evidências científicas e processos de trabalho) seguiu as etapas recomendadas na literatura, finalizado com 50 itens e IVC total de 0,98.

\section{DESCRITORES}

Parto Normal; Questionários; Estudos de Validação; Saúde da Mulher.

\section{RESUMEN}

Objetivo: Describir las etapas de construcción y validación de un instrumento para análisis de la adhesión a las buenas prácticas en la atención al parto y nacimiento. Método: Investigación metodológica, realizada en tres etapas: elaboración de dimensiones e ítems, validación aparente y de contenido y análisis semántico de los ítems. Resultados: La validez aparente y de contenido fue realizada por 
10 jueces que actúan en la asistencia, enseñanza e investigación. Los ítems con Índice de Validez de Contenido (IVC) $\geq$ a 0,9 fueron mantenidos íntegramente o sofrieron revisiones conforme a las sugerencias de los jueces. El análisis semántico, llevado a cabo dos veces, señaló que no había dificultad en la comprensión de los ítems. Conclusión: El instrumento con tres dimensiones (organización de la red de atención al parto y nacimiento, prácticas basadas en evidencias científicas y procesos laborales) siguió las etapas recomendadas en la literatura, finalizado con 50 ítems e IVC total de $0,98$.

\section{DESCRIPTORES}

Parto Normal; Cuestionarios; Estudios de Validación; Salud de la Mujer.

\section{REFERENCES}

1. World Health Organization. Care in normal birth: a practical guide. Geneva: WHO; 1996.

2. Victora CG, Aquino EM, Carmo Leal M, Monteiro CA, Barros FC, Szwarcwald CL. Maternal and child health in Brazil: progress and challenges. Lancet. 2011; 377(9780):1863-76.

3. Jamas MT, Hoga LAK, Reberte LM. Narrativas de mulheres sobre a assistência recebida em um centro de parto normal. Cad Saúde Pública. 2013;29(12):2436-46.

4. Rocha JA, Novaes PB. Uma reflexão após 23 anos das recomendações da Organização Mundial da Saúde para parto normal. Femina. 2010;38(3):119-26.

5. Rattner D. Humanizing childbirth care: brief theoretical framework. Interface. 2009;13 Supl 1:595-602.

6. Diniz SG. Feminismo, materno-infantilismo e políticas de saúde materna no Brasil. Questões Saúde Reprodutiva. 2013;7(6):119-27.

7. World Health Organization. Trends in maternal mortality: 1990-2013. Estimates by WHO, UNICEF, UNFPA, the World Bank and the United Nations Population Division. Geneva: WHO; 2014.

8. Aquino EML. Reinventing delivery and childbirth in Brazil: back to the future. Cad Saúde Pública. 2014;30 Suppl 1:S8-10.

9. Brasil. Ministério da Saúde. Portaria GM n. 1459, de 24 de junho de 2011. Institui, no âmbito do Sistema Único de Saúde - SUS, a Rede Cegonha. Diário Oficial da União, Brasília, 27 jun. 2011. Seção 1, p. 109.

10. Margalho R, Nazareth C, Caetano AS, Oliveira J, Cunha JS, Meliço-Silvestre AA. Métodos de avaliação e observação clínica de adesão à TARv [Internet]. 2009 [citado 2015 maio 15]. Disponível em: http://www.psicologia.pt/artigos/textos/A0466.pdf

11. Curado MAS, Teles J, Marôco J. Analysis of variables that are not directly observable: influence on decision-making during the research process. Rev Esc Enferm USP [Internet]. 2014 [cited 2015 Apr 15];48(1):146-52. Available from: http://www.scielo.br/pdf/reeusp/ v48n1/0080-6234-reeusp-48-01-146.pdf

12. Demo P. Pesquisa participante: saber pensar e intervir juntos. Brasília: Líber; 2004.

13. Dini AP, Alves DFS, Oliveira HC, Guirardello EB. Validity and reliability of a pediatric patient classification instrument. Rev Latino Am Enfermagem. 2014;22(4):598-603.

14. Pasquali L. Psychometrics. Rev Esc Enferm USP [Internet]. 2009 [cited 2015 Apr 12];43(n.spe):992-9. Available from: http://www.scielo. br/pdf/reeusp/v43nspe/en_a02v43ns.pdf

15. Vituri DW, Matsuda LM. Content valid ation of quality indicators for nursing care evaluation. Rev Esc Enferm USP [Internet]. 2009 [cited 2015 Apr 15];43(2):426-34. Available from: http://www.scielo.br/pdf/reeusp/v43n2/en_a24v43n2.pdf

16. Brasil. Ministério da Saúde; Agência Nacional de Vigilância Sanitária. Resolução RDC n. 36, de 03 de junho de 2008. Dispõe sobre Regulamento Técnico para Funcionamento dos Serviços de Atenção Obstétrica e Neonatal. Diário Oficial da União, Brasília, 4 jun. 2008. Seção 1, p.50.

17. Lacerda RA, Nunes BK, Batista AO, Egry EY, Graziano KU, Angelo M, et al. Evidence-based practices published in Brazil: identification and analysis of their types and methodological approaches. Rev Esc Enferm USP [Internet]. 2011 [cited 2015 Apr 17];45(3):773-82. Available from: http://www.scielo.br/pdf/reeusp/v45n3/en_v45n3a33.pdf

18. Alexandre NMC, Coluci MZO. Content validity in the development and adaptation processes of measurement instruments. Ciênc Saúde Coletiva. 2011;16(7):3061-8.

19. Bellucci Junior JA, Matsuda LM. Construção e validação de instrumento para avaliação do Acolhimento com Classificação de Risco. Rev Bras Enferm. 2012;65(5): 751-7.

20. Pasquali L. Princípios de elaboração de escalas psicológicas. Rev Psiquiatr Clín. 1998; 25(5):206-13.

21. Polit D, Beck CT. The content validity index: are you sure you know what's being reported? Critique and recommendations. Res Nurs Health. 2006;29(5):489-97.

22. Duarte ED, Dittz ES, Madeira LM, Braga PP, Lopes TC. O trabalho em equipe expresso na prática dos profissionais de saúde. Rev Eletr Enf [Internet]. 2012 [citado 2015 mar. 27];14(1):86-94. Disponível em: https://www.fen.ufg.br/fen_revista/v14/n1/pdf/v14n1a10.pdf

23. Leal MDC, Pereira APE, Domingues RMSM, Filha MMT, Dias MAB, Nakamura-Pereira M, et al. Obstetric interventions during labor and childbirth in Brazilian low-risk women. Cad Saúde Pública. 2014;30 Suppl 1:S17-32.

24. Diniz SG. O renascimento do parto, e o que o SUS tem a ver com isso. Interface Comun Saúde Educ. 2014;18(48):217-20.

25. Pasche DF, de Albuquerque Vilela ME, Martins CP. Humanização da atenção ao parto e nascimento no Brasil: pressupostos para uma nova ética na gestão e no cuidado. Tempus Actas Saúde Colet. 2010;4(4):105-17. 
26. Pompeu DA, Rossi LA, Paiva L. Content validation of the nursing diagnosis Nausea. Rev Esc Enferm USP [Internet]. 2014 [cited 2015 Apr 17];48(1):48-56. Available from: http://www.scielo.br/pdf/reeusp/v48n1/0080-6234-reeusp-48-01-48.pdf

27. Joventino ES, Oriá MOB, Sawada NO, Ximenes LB. Apparent and content validation of maternal self-efficiency scale for prevention of childhood diarrhea. Rev Latino Am Enfermagem. 2013;21(1):371-9.

28. Costa PB, Chagas ACMA, Joventino ES, Dod RCM, Oriá MOB, Ximenes LB. Construção e validação de manual educativo para a promoção do aleitamento materno. Rev Rene. 2013;14(6):1160-7. 